\title{
The Differences in The Use of Time Period II between The Dorsal Recumbent Position and The Combination Position in Primigravidian Mothers
}

\author{
Hanifah $^{1)}$, Wagiyo ${ }^{1)}$, Elisa ${ }^{1)}$ \\ 1) Nursing Department, Semarang Health Polytechnic \\ Coresponding author: hanifahazzahroh160@gmail.com
}

\begin{abstract}
Background: Normal labor is influenced by five factors known as 5P, namely passenge (fetus and placenta), passageway (birth canal), powers (strength of contraction / uterine strength, contraction of the abdominal wall muscles, contraction of the diaphragm, and ligament action) ), psychologic maternal and position maternal. The position of labor is one way that can be done to reduce the risk of prolonged labor or when elongated. The position of labor commonly used is the dorsal recumbent position, but a combination of labor positions can also be performed.
\end{abstract}

Purpose: The aim of this study was to determine the differences in the use of time period II between the dorsal recumbent position and the combination position in primigravidian mothers at Roemani Hospital Muhammadiyah Semarang.

Methods: The research method used was Quasy Experiment with the design of the Post Test Only Design Group. The number of samples in this study were 30 respondents who were divided into 2 treatment groups. The sampling technique uses Accidental sampling. Data analysis using Independent t-test.

Results: Based on the results of the Independent test the t-test obtained $p$-value $=0,000$ ( $\mathrm{P}<0.05)$, so that there was a significant difference between the dorsal recumbent position and the combination position of the second stage of labor in primigravidian mothers. The average time period II with the dorsal recumbent position was 24.14 minutes and the average time of the second time with the combination position was 19.71 minutes. The conclusion is that the time period II with the combination position is more effective than dorsal recumbent position.

Conclusion: It's hoped that it can be used as a material consideration to improve the quality of services for midwives or health workers, especially for labor positions so as to shorten the time period II.

\section{Keywords:}

Second Stage of Labor; Combination; Dorsal Recumbent; Lateral

\section{LATAR BELAKANG}

Persalinan merupakan suatu proses membuka dan menutupnya servik uteri yang disertai turunnya janin dan plasenta ke dalam jalan lahir sampai dengan keluar secara lengkap beserta selaputnya yang terjadi pada kehamilan yang sudah cukup bulan (37-42 minggu) 
atau janin telah mencapai posisi presentasi ubun-ubun kecil, presentasi kepala, lahir spontan pervagina dengan kekuatan ibu sendiri tanpa melukai ibu dan bayi kecuali dilakukan episiotomi, berlangsung selama kurang dari 24 jam tanpa komplikasi baik pada ibu maupun bayinya (Wagiyo \& Putrono, 2016).

Dari data yang diambil dari Profil Data Kesehatan Indonesia tahun 2017, didapatkan data ibu melahirkan di Indonesia sebanyak 5.078.636 jiwa dan ibu bersalin di Jawa Tengah terdapat 564.121 jiwa. Sedangkan bayi lahir hidup di Indonesia sebanyak 4.840.511 jiwa, sedangkan di Jawa Tengah didapatkan data bayi lahir sebanyak 537.258 jiwa. Menurut data dai Profil Kesehatan Provinsi Jawa Tengah, di Kota Semarang pada tahun 2016 terdapat bayi lahir sebanyak 26.337 jiwa. Sedangkan data yang diperoleh dari RS Roemani Muhammadiyah Semarang terdapat 21 ibu primigravida melahirkan secara spontan pada bulan Oktober 2018.

Melihat tingginya angka kelahiran tersebut menjadi menarik perhatian untuk mengetahui lebih banyak tentang persalinan. Menurut Aji, dkk (2016) dalam penelitiannya menyebutkan beberapa hal yang dapat mempengaruhi persalinan diantaranya yaitu passenger (janin), passegeway (jalan lahir), power (kekuatan his dan tenaga), position (posisi persalinan), serta psychologic (psikologi seperti kecemasan ibu). Hal tersebut dapat menyebabkan persalinan lama yang memberikan dampak kepada ibu dan bayi. Akibat dari persalinan yang lama bagi ibu antara lain dapat menyebabkan infeksi postpartum, ruptur uteri, cincin retraksi patologis, dan cidera otot dasar panggul. Sedangkan akibat yang akan terjadi pada bayi yaitu terjadinya kaput suksedaneum, molase kepala bayi, dan asfiksia yang sering terjadi dan banyak ditemui. (Prawirohardjo, 2010)

Salah satu solusi untuk membantu mempercepat persalinan kala II yaitu dengan melakukan pengaturan posisi persalinan. Menurut JNPK-KR (2008) dalam jurnal penelitian Pantiawati, dkk (2016) yang berjudul "Efektivitas Posisi Persalinan dengan Waktu Persalinan Kala II pada Ibu Bersalin Primipara di RSKBD Panti Nugroho Purbalingga tahun 2016", pengaturan posisi ibu dalam persalinan merupakan salah satu hal yang dapat dilakukan untuk membantu mempercepat kala II. Penolong persalinan dapat membantu untuk memperoleh posisi yang paling nyaman. Beberapa posisi meneran pada proses persalinan dianjurkan diantaranya adalah posisi dorsal recumbent, berbaring ke kiri (lateral), setengah duduk, duduk, merangkak, dan jongkok.

Berdasarkan hasil sebuah penelitian yang dilakukan oleh Martini, dkk di Puskesmas Balaraja pada tahun 2016 menunjukkan hasil bahwa terdapat perbedaan lama kala II antara posisi setengah duduk dengan posisi miring yaitu dengan nilai rata-rata pada posisi setengah duduk 35,4 menit, sedangkan rata-rata pada posisi miring 29,5 menit, dari nilai tersebut terdapat perbedaan nilai yaitu 5,9 menit.

Hasil penelitian lain yang dilakukan oleh Pantiawati pada (2016) menunjukkan rata-rata responden yang bersalin dengan posisi litotomi waktu persalinan KALA II adalah 23, 33 menit, rata-rata responden yang bersalin dengan posisi dorsal recumbent waktu persalinan KALA II adalah 22,80 menit, nilai $p$-value berdasarkan hasil perhitungan diatas sebesar 0,069 . Ha ditolak sehingga dapat disimpulkan bahwa tidak ada perbedaan 
antara posisi persalinan litotomi dan posisi dorsal recumbent pada ibu primipara dengan waktu persalinan KALA II.

Berdasarkan data dan fakta dari hasil penelitian yang telah dijabarkan pada latar belakang di atas, maka perlu untuk meneliti efektivitas posisi persalinan antara posisi dorsal recumbent dengan kombinasi posisi lateral dan dorsal recumbent terhadap lama waktu persalinan kala II.

\section{TUJUAN}

Untuk menganalisis efektivitas posisi persalinan antara posisi dorsal recumbent dengan kombinasi posisi lateral dan dorsal recumbent terhadap lama waktu persalinan kala II.

\section{METODE}

Penelitian ini menggunakan desain penelitian Quasy Experiment. Penelitian ini dirancang dengan menggunakan rancangan post test only with control group design untuk mendapatkan gambaran perbedaan lama waktu persalinan kala II antara posisi dorsal recumbent dan posisi kombinasi pada ibu primigravida. Dimana kelompok dengan perlakuan posisi dorsal recumbent merupakan kelompok kontrol. Sehingga peneliti akan menggunakan dua kelompok sampel yang meliputi kelompok kontrol dengan intervensi posisi dorsal recumbent dan kelompok dengan intervensi posisi kombinasi yang kemudian akan diobservasi untuk mengetahui efektivitas antara posisi persalinan dorsal recumbent dengan posisi kombinasi terhadap lama waktu persalinan kala II sebagai hasil dari penelitian. Sampel yang digunakan 30 ibu hamil pada kala II persalinan, dengan menggunakan accidental sampling technic. Analisa data menggunakan independent t-test.

\section{HASIL}

Pada penelitian ini didapatkan sampel 30 responden yang sudah memenuhi kriteria inklusi peneliti, dimana responden dibagi menjadi 2 kelompok yaitu 15 responden sebagai kelompok dengan posisi dorsal recumbent dan 15 responden sebagai kelompok dengan posisi kombinasi.

Tabel 1 Karakteristik berdasarkan usia responden dan usia kehamilan dalam tahun

$$
(n=30)
$$

\begin{tabular}{ccccccc}
\hline Variabel & Kelompok & Mean & Median & SD & Min & Maks \\
\hline Usia & $\begin{array}{c}\text { Posisi Dorsal } \\
\text { Recumbent } \\
\text { Posisi }\end{array}$ & 23,64 & 24 & 2,735 & 18 & 27 \\
$\begin{array}{c}\text { Kombinasi } \\
\text { Usia }\end{array}$ & $\begin{array}{c}\text { Posisi Dorsal } \\
\text { Recumbent } \\
\text { Kehamilan }\end{array}$ & 38,14 & 23,50 & 2,627 & 18 & 28 \\
& $\begin{array}{c}\text { Posisi } \\
\text { Kombinasi }\end{array}$ & 38,86 & 39 & 1,027 & 37 & 40 \\
\hline
\end{tabular}


Tabel 2 Distribusi frekuensi karakteristik berdasarkan pendidikan dan pekerjaan responden $(\mathrm{n}=30)$

\begin{tabular}{lcccc}
\hline \multirow{2}{*}{ Variabel } & \multicolumn{2}{c}{ Kelompok Dorsal Recumbent } & \multicolumn{2}{c}{ Kelompok Kombinasi } \\
\cline { 2 - 5 } & Frekuensi & $\begin{array}{l}\text { Presentase } \\
(\%)\end{array}$ & Frekuensi & $\begin{array}{c}\text { Presentase } \\
(\%)\end{array}$ \\
\hline Pendidikan & 3 & 20 & 3 & 20 \\
SD & 5 & 33,3 & 4 & 26,7 \\
SMP & 6 & 40 & 5 & 33,3 \\
SMA & 1 & 6,7 & 3 & 20 \\
Perguruan Tinggi & & & & \\
Pekerjaan & & 53,3 & 10 & 66,7 \\
Bekerja & 8 & 46,7 & 5 & 33,3 \\
Tidak Bekerja & 7 & & & \\
\hline
\end{tabular}

Dari tabel 1 dan 2 didapatkan rata-rata usia ibu hamil adalah 23 tahun dengan usia kehamilan 38 minggu. Kebanyakan lulusan SMP dan SMA dengan status sebagai ibu rumah tangga dan bekerja.

Tabel 3 Distribusi lama waktu persalinan kala II dengan posisi dorsal recumbent dalam menit $(n=30)$

\begin{tabular}{cccccc}
\hline Variabel & Mean & Median & SD & Min & Maks \\
\hline $\begin{array}{c}\text { Lama Waktu Kala } \\
\text { II dengan Posisi } \\
\text { Dorsal Recumbent }\end{array}$ & 24,14 & 24 & 2,248 & 20 & 28 \\
\hline
\end{tabular}

Tabel 4 Disrtribusi lama waktu persalinan kala II dengan posisi kombinasi dalam menit $(\mathrm{n}=30)$

\begin{tabular}{cccccc}
\hline Variabel & Mean & Median & SD & Min & Maks \\
\hline $\begin{array}{c}\text { Lama Waktu Kala II } \\
\begin{array}{c}\text { dengan Posisi } \\
\text { Kombinasi }\end{array}\end{array}$ & 19,71 & 19,50 & 1,590 & 18 & 23 \\
\hline
\end{tabular}

Data yang diperoleh dilakukan uji normalitas menggunakan uji Shapiro-wilk karena jumlah responden $<50$ dimana didapatkan hasil nilai sig posisi dorsal recumbent 0,966 dan nilai sig posisi kombinasi 0,094 dengan kata lain dapat dilihat bahwa nilai signifikan pada kedua posisi > 0,05 sehingga data yang diperoleh berdistribusi normal. 
Kemudian karena data berdistribusi normal maka untuk melihat perbedaan dari kedua kelompok dilakukan uji Independent T-Test.

Tabel 5 Hasil analisa Independent t-test dan lama waktu persalinan kala II pada ibu primigravida setelah dilakukan perlakuan $(\mathrm{n}=30)$

\begin{tabular}{lccccc}
\hline & & F & Sig & df & Sig (2-tailed) \\
\cline { 2 - 6 } Waktu & $\begin{array}{c}\text { Equal Variances } \\
\text { kala II } \\
\begin{array}{c}\text { assumed } \\
\text { Equal Variances } \\
\text { not assumed }\end{array}\end{array}$ &, 894 &, 365 & 28 &, 000 \\
\hline
\end{tabular}

Tabel 6 Hasil analisa efektivitas posisi dorsal recumbent dengan posisi kombinasi terhadap lama waktu persalinan kala II pada ibu primigravida

\begin{tabular}{cccc}
\hline Variabel & Mean & SD & p value \\
\hline $\begin{array}{c}\text { Lama waktu persalinan } \\
\text { kala II Posisi Dorsal } \\
\text { Recumbent }\end{array}$ & 24,14 & 2,248 &, 000 \\
$\begin{array}{c}\text { Lama waktu persalinan } \\
\text { kala II Posisi Kombinasi }\end{array}$ & 19,71 & 1,590 &, 000 \\
\hline
\end{tabular}

Rata-rata waktu lama persalinan kala II posisi dorsal recumbent 24 menit dan posisi kombinasi 19 menit. Ada pengaruh perlakuan lama waktu persalinan dengan posisi dorsal recumbent dan kombinasi dengan $p$ value $=0,00$.

\section{PEMBAHASAN}

Berdasarkan karakteristik usia responden didapatkan hasil dimana rata-rata usia responden yang melahirkan dengan posisi dorsal recumbent 23,64 tahun dengan usia terendah yaitu 18 tahun dan usia tertinggi adalah 27 tahun. Sedangkan rata-rata usia responden yang melahirkan dengan posisi kombinasi adalah 23,14 tahun dengan usia terendah yaitu 18 tahun dan usia tertinggi adalah 28 tahun.

Berdasarkan data tersebut dapat dilihat bahwa terdapat responden di bawah umur 20 tahun yang melahirkan secara normal (spontan). Hal ini berbeda dengan hasil penelitian Prihandini, dkk (2016) menyatakan bahwa usia ibu melahirkan kurang dari 20 tahun dan lebih dari 35 tahun dikatakan sebagai usia berisiko, sedangkan usia tidak berisiko yaitu rentang usia 20 - 35 tahun. Penelitian lain yang dilakukan oleh Afritayeni (2017), mendapatkan hasil bahwa ibu yang memiliki umur kurang dari 20 tahun akan mengalami proses persalinan pertama kali dalam hidupnya, umur yang relatif masih muda tersebut akan menimbulkan respon kecemasan dalam dirinya karena merupakan persalinan pertamanya. 
Ibu yang melahirkan diusia yang relatif muda cenderung tidak tahan terhadap sakit ketika mengalami kontraksi, hal tersebut menyebabkan ibu tidak mau mengedan sehingga dapat memperlambat kala II. Selain itu ibu yang melakukan persalinan di bawah umur 20 tahun dianggap belum siap secara emosional dan juga mental, sehingga akan berisiko buruk bagi ibu dan bayinya (Prihandini, 2016). Penelitian lain yang dilakukan oleh Jannah dalam Abdurradjak, dkk (2016) mendapatkan hasil bahwa persalinan yang terjadi pada usia dini $<20$ tahun terjadi komplikasi kehamilan seperti partus lama.

Pada penelitian ini ibu usia $<20$ tahun dapat melahirkan normal, hal ini dipengaruhi oleh beberapa faktor. Sebagian besar responden penelitian ini merupakan ibu yang rajin mengikuti ANC sehingga responden lebih siap menghadapi persalinan serta mampu mengontrol psikis, paham cara mengedan yang baik. Selain itu semua responden tidak ada yang memiliki kelainan panggul seperti panggul sempit, sehingga ibu tidak mengalami kesulitan dalam persalinan maupun komplikasi persalinan. Seperti halnya penelitian yang dilakukan oleh Prihandini (2016) yang menyatakan bahwa ibu yang rutin melakukan ANC atau kelas ibu hamil akan sangat membantu dalam proses persalinan, karena ibu mendapatkan banyak pengetahuan tentang persiapan persalinan sehingga ibu akan lebih siap dan dapat menekan risiko terjadinya komplikasi persalinan.

Hasil penelitian ini, didapatkan data usia kehamilan rata-rata pada kelompok responden dengan posisi dorsal recumbent yaitu 38,57 minggu dengan usia kehamilan minimal yaitu 37 minggu dan usia kehamilan maksimal 40 minggu. Sedangkan rata-rata usia kehamilan pada kelompok posisi kombinasi yaitu 38,86 minggu dengan usia kehamilan minimal 37 minggu dan maksimal 40 minggu.

Berdasarkan data di atas, menunjukkan bahwa tidak ada perbedaan rentang usia kehamilan antara posisi dorsal recumbent dengan posisi kombinasi. Usia kehamilan semua responden berada pada rentang usia kehamilan normal untuk dapat melakukan persalinan spontan yaitu dalam rentang usia 37 - 42 minggu. Hal tersebut sesuai dengan teori yang menyatakan bahwa persalinan normal terjadi pada usia kehamilan cukup bulan atau yang disebut kehamilan aterm yaitu rentang usia kehamilan 37 - 42 minggu (Reeder, 2011). Selain itu hasil penelitian lain menyatakan persalinan pada usia kehamilan aterm atau cukup bulan merupakan persalinan yang cukup aman dan memiliki resiko $5-7$ kali lebih kecil dibanding dengan persalinan pada usia kehamilan postterm (Handaria dkk, 2014).

Dari analisa karakteristik responden berdasarkan data pendidikan responden menunjukkan bahwa paling banyak 11 responden $(36,7 \%)$ menempuh pendidikan SMA, kemudian 9 responden $(30 \%)$ menempuh pendidikan SMP, 6 responden $(20 \%)$ yang menempuh pendidikan SD, dan yang paling sedikit yaitu responden dengan pendidikan perguruan tinggi sebanyak 4 responden (13,3 \%). Pendidikan ibu dapat mempengaruhi penyerapan informasi yang didapatkan ibu tentang persiapan persalinan. Pendidikan ibu yang kebanyakan telah melewati pendidikan dasar dapat membantu ibu dalam memahami suatu informasi. Hal ini sesuai penelitian yang dilakukan oleh Ningsih (2017) membuktikan bahwa semakin tinggi tingkat pendidikan seseorang maka semakin mudah dalam penerimaan suatu informasi sehingga semakin banyak pula pengetahuan yang dimiliki dan sebaliknya pendidikan seseorang yang kurang menghambat sikap seseorang terhadap nilai-nilai baru yang diperkenalkan. 
Menurut Ristica (2017) pendidikan berarti bimbingan yang diberikan seseorang terhadap perkembangan orang lain menuju ke arah cita-cita tertentu yang menentukan manusia untuk berbuat dan mengisi kehidupan untuk mencapai keselamatan dan kebahagiaan. Pendidikan diperlukan untuk mendapat informasi misalnya hal-hal yang menunjang kesehatan sehingga dapat meningkatkan kualitas hidup. Pendidikan dapat mempengaruhi seseorang termasuk juga perilaku seseorang akan pola hidup terutama dalam memotivasi untuk sikap berperan serta dalam pembangunan pada umumnya makin tinggi pendidikan seseorang makin mudah menerima informasi. Menurut penelitian Prihandini (2016) semakin tinggi pendidikan ibu serta rutin mengikuti kelas ibu hamil (ANC) akan mudah mempersepsikan diri dan mempermudah ibu dalam memahami tentang persalinan yang akan dihadapinya.

Berdasarkan analisa karakteristik responden menurut pekerjaan didapatkan data bahwa sebagian besar responden merupakan pekerja yaitu sebanyak 18 responden (60\%), sedangkan sisanya 12 responden $(40 \%)$ merupakan ibu yang tidak bekerja (ibu rumah tangga). Hasil penelitian Budiman, dkk (2017) mengemukakan bahwa tidak terdapat hubungan yang signifikan antara pekerjaan dengan persalinan. Ibu yang bekerja maupun yang tidak bekerja (ibu rumah tangga) juga dapat memiliki anak dan dapat melahirkan secara normal (spontan).

Penelitian yang lain menunjukkan bahwa ibu yang bekerja mempunyai tingkat pengetahuan yang baik daripada ibu yang tidak bekerja karena pada ibu yang bekerja akan banyak peluang untuk mendapatkan informasi seputar keadaanya (Budiman, 2017). Sedangkan menurut penelitian Rusmita (2014) mengemukakan ibu yang tidak bekerja tidak memiliki pengetahuan dan pengalaman yang didapat dari lingkungan kerja dan media serta fasilitas pendukung yang terdapat di tempat kerja mereka.

\section{Gambaran Lama Waktu Persalinan Kala II dengan Posisi Dorsal Recumbent pada Ibu Primigravida}

Berdasarkan hasil analisa data penelitian ini menunjukkan bahwa rata-rata lama waktu persalinan kala II pada ibu primigravida dengan posisi dorsal recumbent adalah 24,14 menit dengan waktu paling cepat 20 menit dan waktu yang paling lama yaitu 28 menit. Persalinan normal terjadi pada ibu dengan kehamilan cukup bulan yaitu usia kehamilan 37 - 42 minggu yang merupakan suatu proses membuka dan menutupnya serviks uteri yang kemudian terjadi penurunan janin dan plasenta ke jalan lahir sehingga bayi lahir pervagina dengan kekuatan ibu sendiri tanpa komplikasi pada ibu maupun bayi yang berlangsung kurang dari 24 jam (Wagiyo \& Putrono, 2016). Dalam proses persalinan terdapat empat tahap yaitu kala I, kala II, kala III, dan kala IV. Kala II merupakan tahapan terpenting dalam proses persalinan karena tahap ini merupakan penentu bayi lahir. Tahap dimana sejak ibu pembukaan lengkap sampai dengan bayi lahir. Pada tahap ini terkadang ibu mengalami kala II memanjang. Normal lama waktu persalinan kala II yaitu selama 50 menit untuk ibu primigravida. Persalinan lama dapat berakibat buruk bagi ibu maupun untuk bayi (Prawirohardjo, 2010).

Menurut Aji, dkk (2014) beberapa faktor yang dapat mempengaruhi proses persalinan yang disebut dengan 5P yaitu Passenger, Passageway, Power, Position, dan Psychologic. Berdasarkan faktor Passenger, berat badan bayi lahir normal yaitu dalam 
rentang 2500 - 4000 gram (Wagiyo, 2016). Dari penelitian yang dilakukan, didapatkan bahwa tidak ditemukan bayi yang lahir dengan berat badan diluar rentang normal tersebut serta bayi lahir dengan presentasi kepala, serta tidak ada bayi yang lahir dengan kelainan ukuran kepala. Selain itu semua responden tidak mengalami kelainan letak plasenta yang menghalangi jalan lahir.

Berdasarkan faktor Passageway, dalam penelitian ini tidak terdapat responden dengan kelainan panggul sehingga semua responden dapat melahirkan secara spontan. Kemudian faktor selanjutnya yaitu Power, kekuatan ibu dalam proses melahirkan. Menurut Wagiyo (2016), kekuatan dalam proses persalinan dibagi menjadi 2 yaitu kekuatan kontraksi uterus yang disebut kekuatan primer dan kekuatan mengedan sebagai kekuatan sekunder. Dalam penelitian ini, semua responden diajarkan cara mengedan yang benar sebelum penolong persalinan memulai memimpin persalinan. Selain itu, responden mampu mengikuti arahan yang diberikan oleh pemimpin persalinan selama berlangsungnya proses persalinan.

Faktor lainnya yaitu faktor Psychologic ibu saat proses persalinan. Pada saat sebelum dipimpin persalinan, semua responden didampingi dan oleh suami dan keluarganya serta mendapat dukungan dari orang terdekatnya sehingga semua responden lebih tenang, tidak terlalu cemas menghadapi nyeri pada saat proses persalinan. Menurut Damayanti (2014), ibu melahirkan dengan dukungan keluarga dan orang-orang yang dicintainya akan berdampak baik pada psikologi ibu.

Faktor terakhir adalah faktor Position, posisi ibu pada saat melahirkan. Menurut Hikmah, dkk (2016), posisi ibu melahirkan mempengaruhi lama waktu persalinan serta kenyamanan ibu. Posisi kala II yang efektif dapat membantu mempercepat proses lahirnya bayi dan juga memberikan kenyamanan pada ibu. Terdapat beberapa posisi yang dianjurkan untuk ibu melahirkan salah satunya yaitu posisi dorsal recumbent. Posisi ini merupakan posisi yang sering diterapkan pada ibu melahirkan, karena posisi ini sangat sederhana dan sangat mudah untuk dilakukan.

Menurut Pantiawati, dkk (2016) menyatakan posisi dorsal recumbent memudahkan penolong persalinan dalam memantau pembukaan jalan lahir dan turunnya kepala bayi sehingga kepala bayi mudah diarahkan dan dipegang mengikuti putaran paksi kepala, serta mengurangi resiko terjadinya lilitan tali pusat dan juga mempermudah jika terjadi lilitan tali pusat maka kepala bayi akan diarahkan mendekati perut ibu.

Hasil studi penelitian yang meneliti tentang efektivitas posisi melahirkan antara posisi dorsal recumbent dan lithotomi menyatakan bahwa melahirkan dengan rata-rata posisi dorsal recumbent memiliki waktu sedikit cepat 0.53 detik jika dibandingkan dengan posisi lithotomi yang mana rata-rata lama waktu pada posisi dorsal recumbent 22,80 menit (Pantiawati, dkk, 2016). 


\section{Gambaran Lama Waktu Persalinan Kala II dengan Posisi Kombinasi pada Ibu Primigravida}

Pada penelitian ini dilakukan pengaturan posisi kombinasi antara posisi lateral dengan posisi dorsal recumbent. Setelah responden mengalami pembukaan lengkap, responden diposisikan lateral terlebih dahulu hingga kepala sudah masuk vagina, kemudian setelah itu baru dilakukan pergantian posisi yaitu diposisikan dorsal recumbent untuk melahirkan bayinya.

Berdasarkan dari hasil analisa penelitian ini mendapatkan data rata-rata lama waktu kala II pada ibu primigravida dengan posisi kombinasi antara posisi lateral dan dorsal recumbent yaitu 19,71 menit dengan waktu paling cepat 18 menit dan waktu paling lama yaitu 23 menit. Hasil penelitian ini didukung teori yang dikemukakan oleh Reeder (2011) dimana posisi lateral dapat meningkatkan kenyamanan, meningkatkan aliran darah plasenta dan mencegah hipontensi, menguatkan kontraksi uterus, lebih efisien, perineum lebih relaks sehingga mengurangi potensi untuk dilakukan laserasi. Penelitian ini didukung penelitian yang dilakukan oleh Martini, dkk (2016) yang menunjukkan hasil bahwa terdapat perbedaan lama kala II antara posisi setengah duduk dengan posisi lateral yaitu dengan nilai rata-rata pada posisi setengah duduk 35,4 menit, sedangkan rata-rata pada posisi lateralg 29,5 menit, dari nilai tersebut terdapat selisih perbedaan nilai yaitu 5,9 menit. Sehingga dapat disimpulkan bahwa posisi lateral lebih cepat dalam proses persalinan dibanding dengan posisi setengah duduk.

Posisi lain yang digunakan dalam penelitian ini adalah posisi dorsal recumbent seperti yang sudah dijelaskan bahwa posisi ini merupakan posisi yang dianggap mudah dilakukan dan sangat sederhana, sehingga digunakan dalam inovasi penelitian. Pernyataan ini juga didukung hasil penelitian yang dilakukan oleh Pantiawati dkk (2016) yang berjudul efektivitas posisi melahirkan antara posisi dorsal recumbent dan lithotomi dimana didapatkan hasil bahwa melahirkan dengan rata-rata posisi dorsal recumbent memiliki waktu sedikit cepat 0.53 detik jika dibandingkan dengan posisi lithotomi. Menurut teori yang dikemukakan oleh Sukarni (2013) dalam bukunya, menyatakan bahwa melahirkan pada saat kepala bayi sudah memasuki vagina dengan posisi dorsal recumbent dapat menyebabkan pintu bawah panggul semakin lentur jadi lebih maksimum sehingga bayi akan mudah dilahirkan.

\section{Efektivitas Posisi Dorsal Recumbent dengan Posisi Kombinasi terhadap Lama Waktu Persalinan Kala II pada Ibu Primigravida}

Dari penelitian ini didapatkan hasil uji statistik Independent $t$-test yang menunjukkan bahwa terdapat perbedaan yang bermakna antara posisi dorsal recumbent dengan posisi kombinasi pada ibu primigravida di RS Roemani Muhammadiyah Semarang. Hal tersebut dibuktikan dengan data hasil bahwa didapatkan hasil $\mathrm{f}=0,894$, selain itu didapatkan pula hasil $\mathrm{p}=0,365$ sehingga data tersebut homogen karena $\mathrm{p}>0,05$. Selanjutnya didapatkan data hasil sig $=0,000$ yang berarti $($ sig $=0,000)<0,05$ maka dapat disimpulkan bahwa hipotesis (Ha) diterima yang artinya terdapat perbedaan yang signifikan antara posisi dorsal recumbent dengan posisi kombinasi terhadap lama waktu persalinan kala II pada ibu primigravida di RS Roemani Muhammadiyah Semarang. 
Hasil penelitian ini didukung oleh teori yang menyatakan bahwa pada saat menolong persalinan terutama pada kala II persalinan ibu dianjurkan untuk mencoba posisi-posisi yang nyaman selama persalinan dan melahirkan bayi dengan keuntungan memudahkan dalam menolong persalinan dan persalinan berlangsung lebih nyaman. Mengubah-ubah posisi secara teratur selama kala II dapat membantu kemajuan persalinan (Saifudin, 2014). Mengubah-ubah posisi secara teratur selama kala II karena hal ini dapat membantu kemajuan persalinan, mencari posisi meneran yang paling efektif dan menjaga sirkulasi utero-plasenter tetap baik (JNPK-KR, 2008).

Lama waktu kala II dipengaruhi oleh beberapa faktor antara lain kelainan letak janin, kelainan-kelainan panggul, kelainan kekuatan his dan mengejan, pimpinan persalinan yang salah, janin besar atau ada kelainan congenital, perut gantung, grandemulti, ketuban pecah dini ketika servik masih menutup, keras dan belum mendatar, analgesi dan anestesi yang berlebihan dalam fase laten, wanita yang cemas dan ketakutan. (Prawirohardjo, 2014).

Teori yang menyatakan bahwa posisi lateral dan dorsal recumbent efektif dalam meminimalkan lama waktu persalinan kala II pada ibu primigravida karena tidak dapat menyebabkan hipotensi yang disebabkan oleh bobot uterus dan isinya menekan aorta, vena cava inferior serta pembuluh-pembuluh darah lain sehingga menyebabkan suplai darah ke janin menjadi berkurang, dimana akhirnya ibu dapat pingsan dan bayi mengalami fetal distress ataupun anoksia janin sehingga tidak terjadinya risiko laserasi perineum (Eniyati, 2012). Dari hasil penelitian terdahulu yang dilakukan oleh Nor Aisyah (2013) dengan hasil bahwa penelitian yang dilakukannya terdapat hasil bermakna yang mana rata-rata lama waktu kala II pada posisi telentang 26,46 menit dan posisi kombinasi 21,33 menit sehingga terdapat perbedaan rerata 5,13 menit.

\section{SIMPULAN}

Hasil analisis dengan menggunakan uji Independent t-test, didapatkan p-value 0,000 yang menunjukkan ada perbedaan yang signifikan antara posisi dorsal recumbent dan posisi kombinasi terhadap lama waktu persalinan kala II pada ibu primigravida di RS Roemani Muhammadiyah Semarang dengan perbedaan rata-rata lama waktu antara kedua posisi tersebut yaitu 4,43 menit. Posisi kombinasi lebih cepat dalam persalinan kala II dibandingkan dengan posisi dorsal recumbent. Penelitian ini terbukti posisi kombinasi yang lebih efektif terhadap lama waktu kala II diharapkan dapat dijadikan sebagai sumber informasi dalam penelitian selanjutnya serta peneliti lain dapat menambah responden sehingga hasil penelitian dapat digeneralisasikan.

\section{REFERENSI}

Abdurradjak, K., Linda M.M., John J. E. (2017). Karakteristik Kehamilan dan Persalinan pada Usia <20 Tahun di RSUP Prof. Dr. R. D. Kandou Manado. Jurnal e-Clinic (eCl), Volume 4, Nomor 1, Januari-Juni 2016. 
Afritayeni. (2017). Hubungan Umur, Paritas dan Pendamping Persalinan dengan Intensitas Nyeri Persalinan Kala I. Journal Endurance 2(2) June 2017 (178185).

Aji, F. S., Elisa, \& Wagiyo. (2014). Pengaruh Posisi Persalinan Antara Posisi Lateral dengan Posisi Lithotomy terhadap Lama Persalinan Kala II Ibu Primigravida di Rumah Bersalin Mardi Rahayu Semarang Tahun 2014. Jurnal Ilmu Keperawatan dan Kebidanan, 1-7.

Budiman, E., Rina, K., \& Jill, L. (2017). Hubungan Tingkat Pendidikan, Pekerjaan, Status Ekonomi dengan Paritas Puskesmas Manado. e-Journal Keperawatan(eKp) Volume 5 Nomor 1, Februari 2017.

Damayanti, Eka Putri, dkk. (2014). Asuhan Kebidanan Komprehensif pada Ibu Bersalin dan Bayi Baru Lahir. Yogyakarta: Deepublish.

Eniyati. (2012). Asuhan Kebidanan pada Ibu Bersalin. Yogyakarta: Pustaka Belajar.

Halimatussakdiah. (2016). Lamanya Persalinan Kala I dan II pada Ibu Multipara dengan Apgar Score Bayi Baru Lahir. Jurnal Action: Aceh Nutrition Journal, Mei 2017; 2(1): 6.12 .

Handaria, D., Ika, D. K., \& Azmi, Y. (2014). Hubungan Usia Kehamilan dengan Kejadian Makrosomia. Repository Universitas Muhammadiyah Semarang.

Hikmah, Martini, T., \& Tyas, A. M. (2016). Analisis Perbedaan Posisi Meneran Terlentang dan Kombinasi terhadap Lama Kala II dan Kejadian Ruptur Perineum pada Ibu Bersalin. Imj: Indonesian Midwifery Journal 7, 42, 7-16.

JNPK-KR. (2008). Pelatihan Klinik Asuhan Persalinan Normal. Jakarta: JNPK- KR.

Martini, T., Damayanti, W., \& Fratidhina, Y. (2016). Perbedaan Posisi Miring dengan Posisi Setengah Duduk terhadap Kemajuan Persalinan Kala II pada Multipara di Puskesmas Balaraja Tahun 2016. Temu Ilmiah Hasil Penelitian dan Pengabdian Masyarakat RAKERNAS AIPKEMA 2016.

Ningsih, Eka S. (2017). Hubungan Tingkat Pendidikan Ibu Hamil Trimester III dengan Keteraturan Kunjungan ANC. Jurnal Midpro, Vol. 9/ No. 2 / Desember 2017.

Nor Aisyah. (2015). Perbedaan Kejadian Ruptur Perineum pada Posisi Mengejan antara Terlentang dan Kombinasi. STIKES Muhammadiyah Kudus.

Notoatmodjo, Soekidjo. (2012). Metodologi Penelitian Kesehatan. Jakarta: Rineka Cipta.

Pantiawati, I., Rahayu, L. D. P., \& Mushovah, D. (2016). Efektivitas Posisi Persalinan dengan Waktu Persalinan Kala II pada Ibu bersalin Primipara di RSKBD Panti Nugroho Purbalingga. Jurnal Ilmiah Kebidanan, 7(2), 62-72.

Prihandini, R. S., Wahyu P., Tulus P. H. (2016). Usia Reproduksi Tidak Sehat dan Jarak Kehamilan yang Terlalu Dekat Meningkatkan Kejadian Abortus di Rumah Sakit Tentara Dokter Soedjono Magelang. Jurnal Kebidanan Vol.5 No.9. April 2016.

Profil Data Kesehatan Indonesia. (2017). Diunduh tanggal 16 Oktober 2018 pukul 21.15 WIB. Dari:http://www.pusdatin.kemkes.go.id/article/view/18041000001/profilkesehatan-i-2017-lampiran.html

Ristica, Octa D. (2017). Hubungan Pengetahuan, Sikap, Dan Dukungan Keluarga Ibu Primigravida Dengan Persiapan Persalinan Normal Di BPM Khairani Asnita, Amd.Keb Tahun 2016. MENARA Ilmu Vol. XI Jilid 1 No.78 November 2017.

Reeder, SJ, Martin, LL \& Griffin, dkk. (2011). Keperawatan Maternitas: Kesehatan Wanita, Bayi \& Keluarga. Jakarta: EGC. 
Rusmita, E. (2015). Pengaruh Senam Hamil Yoga Terhadap Kesiapan Ibu Hamil Menghadapi Persalinan Di RSIA Limijati Bandung. Repository Politeknik Kesehatan TNI AU Ciumbuleuit Bandung.

Saifudin A. B. (2014). Buku Panduan Praktis Pelayanan Maternal dan Neonatal. Jakarta: Yayasan Bina Pustaka Sarwono Prawiroharjo.

Sukarni, Icemi, \& Wahyu. (2013). Buku Ajar Keperawatan Maternitas. Yogyakarta: Nuha Medika.

Wagiyo \& Putrono. (2016). Asuhan Keperawatan Antenatal, Intranatal, dan Bayi Baru Lahir Fisiologi dan Patologis. Yogyakarta: Andi. 